\title{
Phytochemical Study and Evaluation of Cytotoxicity, Antioxidant and Hypolipidemic Properties of Launaea taraxacifolia Leaves Extracts on Cell Lines HepG2 and PLB985
}

\author{
Omédine Koukoui1 ${ }^{*}$, Pascal Agbangnan², Sylviane Boucherie ${ }^{3}$, Mahudro Yovo², \\ Oliver Nusse ${ }^{3}$, Laurent Combettes ${ }^{3}$, Dominique Sohounhloué ${ }^{2}$ \\ ${ }^{1}$ Laboratoire de Physiologie Animale, de Signalisation Cellulaire et de Pharmacologie, FAST/Dassa, Université \\ Polytechnique d'Abomey, Dassa Zoumè, Bénin \\ ${ }^{2}$ Laboratoire d'Etude et de Recherche en Chimie Appliquée, Université d'Abomey-Calavi (LERCA/UAC), Cotonou, \\ Bénin \\ ${ }^{3}$ Laboratoire d'Interactions Cellulaires et de Physiopathologie Hépatique, UMR-S 1174, Université Paris Sud, \\ Paris, France \\ Email: ${ }^{*}$ omedine@yahoo.fr
}

Received 25 May 2015; accepted 21 July 2015; published 24 July 2015

Copyright (C) 2015 by authors and Scientific Research Publishing Inc.

This work is licensed under the Creative Commons Attribution International License (CC BY).

http://creativecommons.org/licenses/by/4.0/

(c) (i) Dpen Access

\begin{abstract}
Launaea taraxacifolia is a leafy vegetable of the family of Asteraceae (Compositae) found in several countries in West Africa including Ghana, Benin and Nigeria. The plant leaves are eaten either fresh as salad or cooked as sauces. They are also consumed as infusion to fight against several diseases including non-communicable diseases such as diabetes and hypertension. Several studies have been conducted in Ghana, Nigeria on the nutritional and medicinal values of this plant but no study has yet been conducted in Benin on the virtues of this plant. In this work we have achieved the phytochemical characterization and evaluated the cytotoxicity as well as hypolipidemic and antioxidant effects of the ethanol-aqueous extracts of Launaea taraxacifolia leaves. Cytotoxicity and hypolipidemic activities have been performed on HepG2 cells; the antioxidant effect has been performed on the PLB985 cells. The results showed that the ethanol-aqueous extracts of Launaea taraxacifolia leaves contained the following metabolites: catechic tannin, flavonoids, phenolic acids, mucilage and leucoanthocyanins. Only very high concentrations $(>20 \mathrm{mg} / \mathrm{ml})$ of leaves extracts are toxic for HepG2 cells. Launaea taraxacifolia leaves have significant antioxidant and hypolipidemic activities.
\end{abstract}

*Corresponding author.

How to cite this paper: Koukoui, O., et al. (2015) Phytochemical Study and Evaluation of Cytotoxicity, Antioxidant and Hypolipidemic Properties of Launaea taraxacifolia Leaves Extracts on Cell Lines HepG2 and PLB985. American Journal of Plant Sciences, 6, 1768-1779. http://dx.doi.org/10.4236/ajps.2015.611177 


\section{Keywords}

\section{Launaea taraxacifolia, Phytochemical, Cytotoxicity, Antioxidant, Hypolipidemic}

\section{Introduction}

Cardiovascular diseases and diabetes are the most common non-communicable diseases in the world. One third of the world population suffers from hypertension and one tenth suffers from diabetes; worldwide, three million and six million people die from hypertension and diabetes respectively a year. $80 \%$ of these deaths occur in low-income countries (Global Status Report on Non-Communicable Diseases, 2010). These diseases are caused by unbalanced diet and lack of physical exercise and affect more and more poor countries. The majority of patients in poor countries use medicinal plants to treat these diseases because modern medicine is too expensive. Cardiovascular diseases and diabetes could come from oxidative stress associated with hyperlipidemia. Indeed it has been shown that hyperlipidemia induces accumulation of fatty acids and triglycerides in the liver which causes liver steatosis and oxidative stress [1] [2]. Oxidative stress is the unbalance between reactive oxygen species (ROS) and antioxidant molecules which leads to cell disorder via the attack of macromolecules such as proteins, nucleic acids and lipids [3]. Hence oxidative stress could induce insulin resistance which would lead to type II diabetes [4]. Moreover hypercholesterolemia could induce the production of free radicals in the cells of vascular wall and could lead to cardiovascular diseases [5]-[7].

Launaea taraxacifolia (L. taraxacifolia) is a leafy vegetable of the family Asteraceae (Compositae) that is present in several African countries including Ghana, Senegal, Benin and Nigeria where it is more known and domesticated [8]. It is ranked among the 10 most important neglected and underutilized plants in Benin and constitutes a high priority for research [9] [10]. L. taraxacifolia is a wild plant that grows singly or in clusters on rocky soil, banks, waste places. It also grows on small fields nearby homes for family consumption. The leaves are eaten fresh as a salad or cooked as sauces. The cooked form of the leaves is also sold by women on several West African countries markets mainly in Benin and Nigeria [8]-[10]. Apart from their use as a food, L. taraxacifolia leaves are widely used in the form of infusion for the treatment of several diseases. Antiviral effects, decreased cholesterol levels, regulation of dyslipidemia and regulation of blood pressure have been reported as virtues of the plant [10]-[13]. Studies on the nutritional value and phytochemical characterization of L. taraxacifolia performed in Nigeria and Ghana revealed that extracts of its leaves were rich in potassium, calcium, magnesium, ascorbic acid, tannins, and flavonoids [13] [14]. These compounds could be responsible for the hypolipidemic, hypoglycemic and antioxidant activities of the plants.

In this work we have achieved the phytochemical characterization of ethanol-aqueous extracts of Benin species of L. taraxacifolia leaves and evaluated its cytotoxicity, hypolipidemic and antioxidant properties in HepG2 and PLB985 cells lines.

\section{Materials and Methods}

\subsection{Materials}

\subsubsection{Collection of L. taraxacifolia Plants}

L. taraxacifolia plants were collected in the month of May, 2014 from sakete in southern of Benin. A specimen was deposited in the National Herbarium of the Department of Botany, Abomey-Calavi University. Samples were dried in the shade at room temperature $\left(25^{\circ} \mathrm{C}\right)$ until stabilization of their mass and then pulverized into coarse powder.

\subsubsection{Biological Materials}

HepG2 cells were obtained from ATCC and PLB985 cells were obtained from Dr. Marie-José Stasia (University Hospital, Grenoble, France).

\subsubsection{Reagents}

Gallic acid, Butyl Hydroxy Anisole (BHA), quercetin and catechin were purchased from Sigma Chemical Co. 
(St. Louis, MO) while 2,2-diphenyl-1-picrylhydrazyl (DPPH) and Folin-Ciocalteu reagent were obtained from Acros Organics (Morris Plains, NJ). All solvents used are analytical grad.

DMEM medium, oleic acids, oil red O, Phorbol Myristate Acetate, luminol were purchased from Sigma (France), RPMI 1640 was obtained from BioWhittaker, (Walkersville, MD, USA), MTS-PMS reagent was obtained from Promega (France).

\subsection{Methods}

\subsubsection{L. taraxacifolia Leaves Extraction}

All samples were ground in a commercial coffee grinder for extraction. The mixture ethanol-water $50 \%(\mathrm{v} / \mathrm{v})$ was used as extraction solvent. The extract was concentrated in vacuo using a rota vapor and the yield $(\mathrm{Y})$ was calculated by the formula below:

$$
Y(\%)=(\text { Mass of extract }) /(\text { Mass of plant material used }) \times 100
$$

\subsubsection{Phytochemical Screening}

We explored the chemical potential of the leaves of L. taraxacifolia by a series of coloring techniques. This phytochemical screening was based on standard coloring reactions and/or the precipitation reactions of the chemical compounds in plants according to the published methods and routinely used in our laboratory.

1) Alkaloids

Three various properties based on the capacity of alkaloids to combine with heavy metals or iodine (Dragendoff's reagent, Mayer's reagent and iodoplatinate test) were implemented [15].

2) Coumarins

The characterization of coumarins was made according to the method described by Rizk [16].

3) Saponosides or saponins: Index foam

Two grams of dry and ground Sorghum caudatum were used to prepare a decoction with $100 \mathrm{~mL}$ of distilled water and submitted to boiling for $30 \mathrm{~min}$, then the resulting solution was divided in 10 tubes: $1 \mathrm{~mL}, 2 \mathrm{~mL}, 3$ $\mathrm{mL}, \ldots, 10 \mathrm{~mL}$ of decoction. The content of each tube was adjusted to $10 \mathrm{~mL}$ with distilled water. Each tube was shaken vigorously in a horizontal position for 15 seconds. After 15 min in vertical position, persistent foam measurement was obtained. If it was close to $1 \mathrm{~cm}$ in the 10th tube, the foam index was calculated by the following formula:

$$
I=\text { foam level }(\mathrm{cm}) \text { in the } 10 \text { th tube } \times 5 / 0.0 \mathrm{X}
$$

The presence of saponins was confirmed by an index exceeding 100 [17].

A qualitative approach on methanolic extracts, prepared according to the method described for research of alkaloids, was done by TLC with $\mathrm{AcOEt} / \mathrm{MeOH} / \mathrm{H}_{2} \mathrm{O}$ (100:13.5:4) as solvent of migration, and was visualized with sulfuric vanillin.

4) Sterols and terpenes

The Sterol and terpenes were identified by Liebermann-Buchard reaction [17].

5) Carotenoids and quinones

We carried out the characterization of:

- carotenoids by the reaction of Carr and Price;

- free anthraquinones by the reaction of Bornträger [18];

- combined quinones (O-heteroside and C-heteroside) by methods of characterization usually used in our laboratory.

6) Polyphenols

The determination of phenolic compounds was made by the reaction of ferric chloride [19].

7) Flavonoids

Flavonoids identification was carried out by the test of cyanidin [20].

8) Anthocyanins

To an infusion, we added $5 \mathrm{ml}$ of $10 \% \mathrm{H}_{2} \mathrm{SO}_{4}$ and $5 \mathrm{ml}$ of $50 \% \mathrm{NH}_{4} \mathrm{OH}$. The appearance of a red color that turned purplish blue in basic medium indicates the presence of anthocyanins [21].

9) Leuco-anthocyanins

$0.5 \mathrm{ml}$ of $12 \mathrm{~N} \mathrm{HCl}$ was poured into $3 \mathrm{ml}$ of hydro-alcoholic extract. The acidified solution was brought to 
boiling water bath for 30 minutes. After cooling, the appearance of a purplish red color indicated the presence of leuco-anthocyanins [19].

10) Mucilages

$1 \mathrm{ml}$ of decoction $10 \%$ and $5 \mathrm{ml}$ of ethyl ether were introduced in a test tube. After ten minutes, obtaining a flocculent precipitate indicated the presence of mucilages [21].

\subsubsection{Quantitative Analysis of Phenolic Compounds}

Total polyphenols: The method of determination of total polyphenols consisted to use a mixture of phosphotungstic and phosphomolybdic acid which was reduced during the oxidation of phenols in the mixture of tungsten blue oxide and molybden [22] [23]. The absorbance was measured by a spectrophotometer (JENWAY $50 / 60 \mathrm{~Hz}$ ) at $765 \mathrm{~nm}$. Gallic acid was used as reference and the total polyphenol content in the extract was expressed in mg of gallic acid equivalents per gram of dry matter.

Total flavonoids: The method of aluminum trichloride $\left(\mathrm{AlCl}_{3}\right)$ was used to quantify the total flavonoids. This technique was based on the formation of the aluminum-flavonoids complex that had a maximum absorption at $500 \mathrm{~nm}$ [24] [25].

Condensed tannins: condensed tannins dosing was achieved by using the method of vanillin sulfuric [26]. The principle of this assay was based on the binding of vanillin aldehyde group on the carbon in position 6 of the ring of the catechol to form a red colored complex chromophore which absorbs at $510 \mathrm{~nm}$.

\subsubsection{Cells Culture}

HepG2 cells (hepatocellular carcinoma cell line) were cultured in $75 \mathrm{~cm}^{2}$ polystyrene flasks with DMEM culture medium to which were added $10 \% \mathrm{FBS}$ and $1 \%$ penicillin streptomycin at $37^{\circ}$ under athmosphere of $5 \% \mathrm{CO}_{2}$.

PLB985 cells are human leukemic cells that are capable of differentiating into neutrophils [27]. They were cultured in RPMI 1640 medium containing L-glutamine, penicillin, streptomycin and $10 \%$ FBS at $37^{\circ}$ under athmosphere of $5 \% \mathrm{CO}_{2}$. They were differentiated in the presence of $1.25 \%$ DMSO [28].

\subsubsection{Cytotoxicity}

Cytotoxicity was performed by the MTS assay [29], the protocol was described by Said et al. [30]. HepG2 cells were plated in 96-multiwell culture plates at $1 \times 10^{5}$ cells per well. After 24 hours the culture medium was replaced with new medium containing $L$. taraxacifolia leaves extracts at various concentrations from $1 \mathrm{mg} / \mathrm{ml}$ to $50 \mathrm{mg} / \mathrm{ml}$. The cells were again incubated for $24 \mathrm{~h}$. To determine the viability of the cells, the reagent (MTSPMS) was added to each well. The plate is incubated for $2 \mathrm{~h}$ in the dark. The absorbance at $490 \mathrm{~nm}$ was read by a plate reader (Perkin Elmer, Walac 1420). The experiment was repeated 3 times. The percentage of viability was given by the formula:

Percentage viability $=$ Absorbance of treated cells/absorbance of untreated cells $\times 100$.

\subsubsection{Hypolipidemic Activity}

1) Induction of lipid accumulation by oleic acid

$10^{5} \mathrm{HepG} 2$ cells were plated on slides for $24 \mathrm{~h}$ in normal culture medium. After 24 hours the culture medium was replaced with either normal culture medium (negative control cells), culture medium without FBS containing 1 $\mathrm{mM}$ of oleic acid (positive control) or culture medium without FBS containing $1 \mathrm{mM}$ of oleic acid and L. taraxacifolia leaves extracts at concentration of $20 \mathrm{mg} / \mathrm{ml}$. The cells were again incubated for $24 \mathrm{~h}$ before lipid staining.

2) Stained with Oil Red O (ORO)

The ORO is a lipid-soluble molecule that can color the lipids [31], the protocol is well described by Cui et al. [32]. After fixing the cells were treated with the ORO for $10 \mathrm{~min}$ before observed under microscope. The lipid droplets were colored in red and indicated lipid accumulation induced by oleic acid in HepG2 cells.

\subsubsection{Antioxidant Activity}

Phorbol myristate acetate (PMA) induces the activity of NADPH oxidase and the production of free radicals in human neutrophils [33]. The production of free radicals [34] was quantified by measuring the luminescence induced by luminol with Walac 1420 plate reader. PLB985 cells were re-suspended in ES buffer containing 10 
$\mu \mathrm{g} / \mathrm{ml}$ of luminol, $4 \mathrm{U} / \mathrm{ml}$ of HRP and leaves extracts $(1-20 \mu \mathrm{g} / \mu \mathrm{l})$ to a final volume of $200 \mu \mathrm{l}$. Cells were stimulated with $100 \mathrm{nM}$ PMA and reactive oxygen species (ROS) production was measured for 15 to 60 minutes [35].

\section{Results and Discussion}

\subsection{Phytochemical Screening}

As we can see in Table 1, various secondary metabolites have been highlighted in the leaves of L. taraxacifolia. The phytochemical screening revealed the presence of catechic tannin, flavonoid, mucilage and leucoanthocyanin whereas saponosids, reducing sugar, Alkaloids, Anthraquinones and Quinone derivatives were absent. The presence of flavonoids, tannins is consistent with previous work in Nigeria [13] and Ghana [14]. However, these authors have revealed the presence of saponosids, terpenoid, cardiac glycoside which we did not find in the Benin species. Variability of plant secondary metabolites from one region to another may depend on several factors. Among these, are the climatic and soil conditions (temperature, sun exposure, drought and salinity), storage conditions and the maturity of the plant.

\subsection{Extraction Yield and Phenolic Compounds Contents (Figure 1)}

The extraction yield of the secondary metabolites from L. taraxacifolia leaves by the mixture ethanol-water is "19.851\%". The total phenol content is expressed as Gallic Acid Equivalent (GAE); the flavonoids content is expressed in mg of Quercetin Equivalent (QE) per gram of dry matter and the tannin content is expressed as mg Catechin Equivalent (CE) per gram of dry matter. The results show that L. taraxacifolia extracts have a high total phenolic and flavonoids contents but a low tannin content: respectively “32.275 \pm 1.11 ” mg GAE/g of dry matter; “56.959 \pm 0.385 ” mg QE/g of dry matter and “3.212 \pm 0.036 ” mg CE/g of dry matter (Figure 1).

Phenolic acids can be distinguished by derivatives of benzoic acid and derivatives of cinnamic acid. The gallic acid (benzoic acid) content of edible plants is generally very low, with the exception of certain red fruits, black radish, onions and tea [36]. With its high concentration of gallic acids, L. taraxacifolia is one of the exception.

Flavonoids include severals derivatives: flavonols, flavones, isoflavones, flavanones, flavanols, anthocyanidins. Flavonols are the most ubiquitous flavonoids in foods and the main representatives are quercetin and kaempfero. The high dose of quercetin in L. taraxacifolia leaves can be explained by the fact that flavonols accumulate in the outer and aerial tissues of plants (skin and leaves) because their biosynthesis is stimulated by light [36].

\subsection{The Cytotoxicity of Ethanol-Aqueous Extracts of L. taraxacifolia Leaves (Figure 2)}

The MTS test is used to assess cell viability. The enzymes involved in cellular redox activity of NADPH are able to reduce MTS to formazan, and then reflect cell viability. The reduction of MTS depends on the cellular metabolic activity and the flow of NADPH. The cells that divide rapidly have a high metabolism and greatly reduce the MTS [37] [38]. The fluorescence emitted at $490 \mathrm{~nm}$ by the formazan then reflects cell viability. The concentrations of $L$. taraxacifolia leaves extracts from " $1 \mu \mathrm{g} / \mu \mathrm{l}$ ” to " $10 \mu \mathrm{g} / \mu \mathrm{l}$ ” had no effect on cell viability; the concentrations from " $10 \mu \mathrm{g} / \mu \mathrm{l}$ ” to " $20 \mu \mathrm{g} / \mu \mathrm{l}$ ” decreased cell viability from $100 \%$ to $84 \%$ and the concentrations from " $20 \mu \mathrm{g} / \mu \mathrm{l}$ ” to " $50 \mu \mathrm{g} / \mu \mathrm{l}$ " caused the fall of $50 \%$ of the cell viability. We could deduce that blood concentrations from " 1 to $10 \mu \mathrm{g} / \mu \mathrm{l}$ " of $L$. taraxacifolia leaves extracts are tolerable and totally non-toxic for cells. The Concentrations of extracts above " $20 \mu \mathrm{g} / \mu \mathrm{l}$ ” gradually decrease cell viability indicating that high concentrations of extracts may be toxic. Daily consumption of polyphenols depends on the consumption of fruits, vegetables, tea, onions, red wine and coffee. It cans reach $1 \mathrm{~g}$ per day in people who eat lots of fruits and vegetables or coffee [38]-[40]. Very few studies have linked the plasma concentration of polyphenols with consumption. Most polyphenols are present in food in the form of esters, glycosides or polymers that cannot be absorbed in their native form. These substances must be hydrolyzed by intestinal enzymes or by colonic microflora before they can be absorbed. The efficiency of absorption is often reduced in this case [36]. The administration of polyphenols in the form of a water-alcohol solution allow to achieve much higher plasma concentration (up to $5 \mu \mathrm{mol} / \mathrm{L}$ ) than when polyphenols are ingested with foods such as onions, apples (“0.3 - 0.75” $\mu \mathrm{mol} / \mathrm{L}$ ) [36] [41]. The dosage of L. taraxacifolia leaves extracts especially in the context of the use as a drug is therefore very important. When 
Table 1. Secondary metabolites identified in L. taraxacifolia.

\begin{tabular}{lcc}
\hline & Secondary metabolites & L. taraxacifolia \\
\cline { 2 - 3 } Tannin & Gallic & - \\
\hline Flavonoids & Catechic & + \\
Mucilage & & + \\
Anthocyanin & & - \\
Leucoanthocyanin & + \\
Reducing sugar & - \\
Anthraquinones & - \\
Alkaloids & - \\
Saponosids & - \\
Quinone derivatives & - \\
\hline
\end{tabular}

+: presence; -: absence.

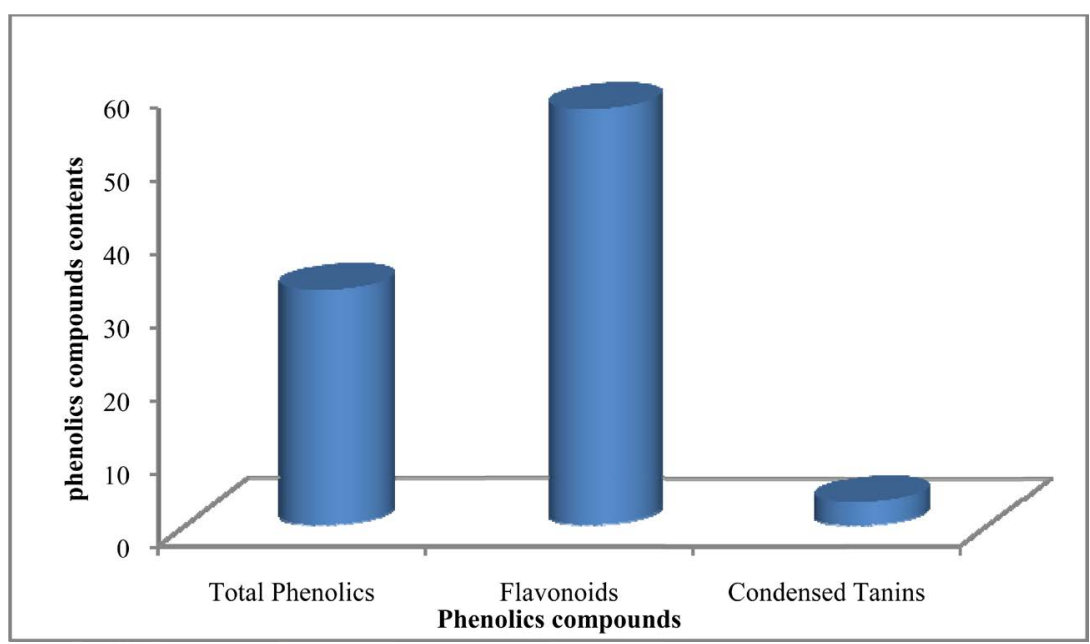

Figure 1. Phenolic coumpound contents of ethanol aqueous extracts of Launaea taraxacifolia. L. taraxacifolia extracts have a high Total phenolic and flavonoids content but a low condensed tannin content: respectively (32.275 \pm 1.113$) \mathrm{mg} / \mathrm{g}$ Total phenol; (56.959 \pm 0.385$) \mathrm{mg} / \mathrm{g}$ Flavonoids and $(3.212 \pm 0.036) \mathrm{mg} / \mathrm{g}$ Tannin.

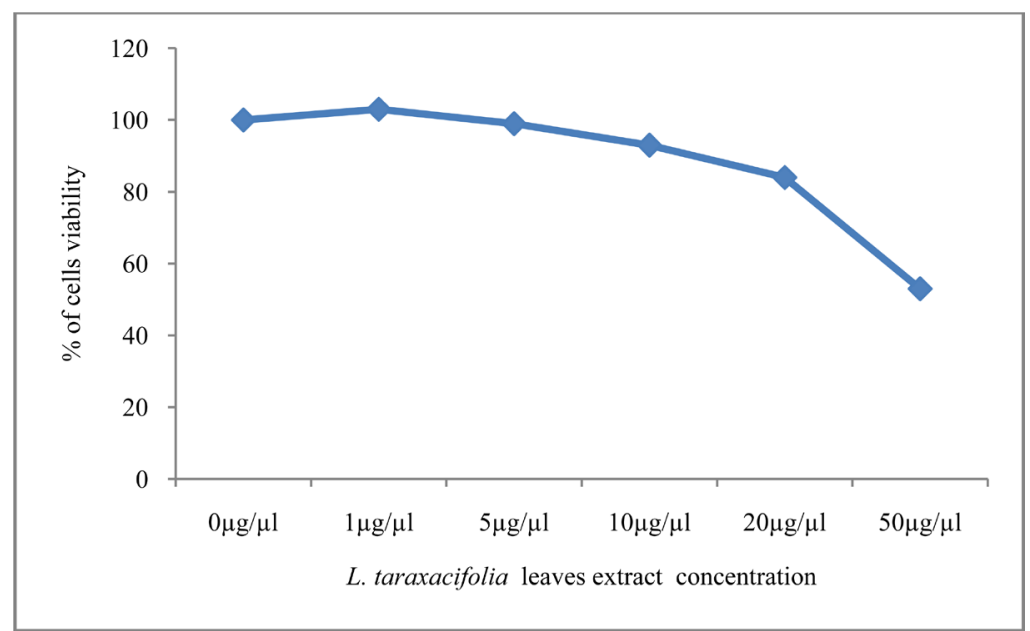

Figure 2. Dose dependent action of $L$. taraxacifolia leaves extracts on HepG2 cells viability. The viability of the HepG2 cells in the presence of different doses of L. taraxacifolia leaves extracts was measured by MTS test. The concentrations from 1 to $10 \mu \mathrm{g} / \mu \mathrm{l}$ of extracts had no effect on cell viability. By cons from $20 \mu \mathrm{g} / \mu \mathrm{l}$ of extracts, a slight decrease in cell viability was observed. The dose of $50 \mu \mathrm{g} / \mu \mathrm{l}$ was toxic because there was $50 \%$ decrease in cell viability. 
radiolabeled polyphenols are given to rats, radioactivity is recovered in blood and in several tissues including brain, endothelial cells, heat, kidney, uterus, mammary gland at the concentrations ranged from $30 \mathrm{ng}$ to $3 \mu \mathrm{g} / \mathrm{g}$ of tissue depending on the dose administered and the tissue considered [42] [43]. The endothelium is one of the primary sites of flavonoids action [44]. The concentration of polyphenols could be higher in tissues than in blood [45] this shows that plasma concentrations are not directly correlated with concentrations in target tissues and could demonstrate that plasma concentrations are not accurate biomarkers of polyphenols exposure.

\subsection{Antioxidant Activity of Ethanol-Aqueous Extracts of L. taraxacifolia Leaves (Figure 3 and Figure 4)}

The antioxidant activity of ethanol-aqueous $L$. taraxacifolia leaves extracts is demonstrated by measuring the production of free radicals by the PLB985 cells in the presence of 100 nM PMA alone or "100 nM" PMA with different concentrations of extracts. It's known that PMA induces the activity of NADPH oxidase in human neutrophils [33]. "100 nM" of PMA induced a strong production of ROS by PLB985 cells but at the presence of extracts concentrations ranging from " $1 \mu \mathrm{g} / \mu \mathrm{l}$ ” to " $20 \mu \mathrm{g} / \mu \mathrm{l}$ ”, there is no production of ROS (Figure 3).

The experiment was repeated with lower concentrations of extracts ("0.05 - $0.5 \mu \mathrm{g} / \mu \mathrm{l}$ ”). Under these conditions ROS production induced by " $100 \mathrm{nM}$ " PMA decreased and slowed considerably depending on the dose and was zero in the presence of " $0.5 \mu \mathrm{g} / \mu \mathrm{l}$ " extracts (Figure 4). The results obtained with the lower doses of extracts have confirmed the result obtained with the higher doses. From " $0.5 \mathrm{mg} / \mathrm{ml}$ " of extracts, ROS production induced by "100 nM" PMA in cells PLB985 was totally canceled. At lower concentrations, the sustained ROS production by the phagocytes appears to overcome the antioxidant capacity towards the end of the measurement These results are very interesting and show that $L$. taraxacifolia leaves extracts may have significant antioxidant effects.

In response to growth factors and cytokines, and during normal metabolic events such as respiration and phagocytosis, eukaryotic cells produce oxidants. To compensate for this, the cells have evolved both enzymatic and nonenzymatic mechanisms to protect against oxidants' toxic effects. The enzymatic mechanisms include the actions of enzymes such as catalase and glutathione peroxidase. The non-enzymatic antioxidants include glutathione, ascorbate. However, in pathophysiologic circumstances, an excess of oxidants can overwhelm the scavenging capacity of cellular antioxidant systems. The subsequent oxidative stress damages the cell's lipids, membranes,

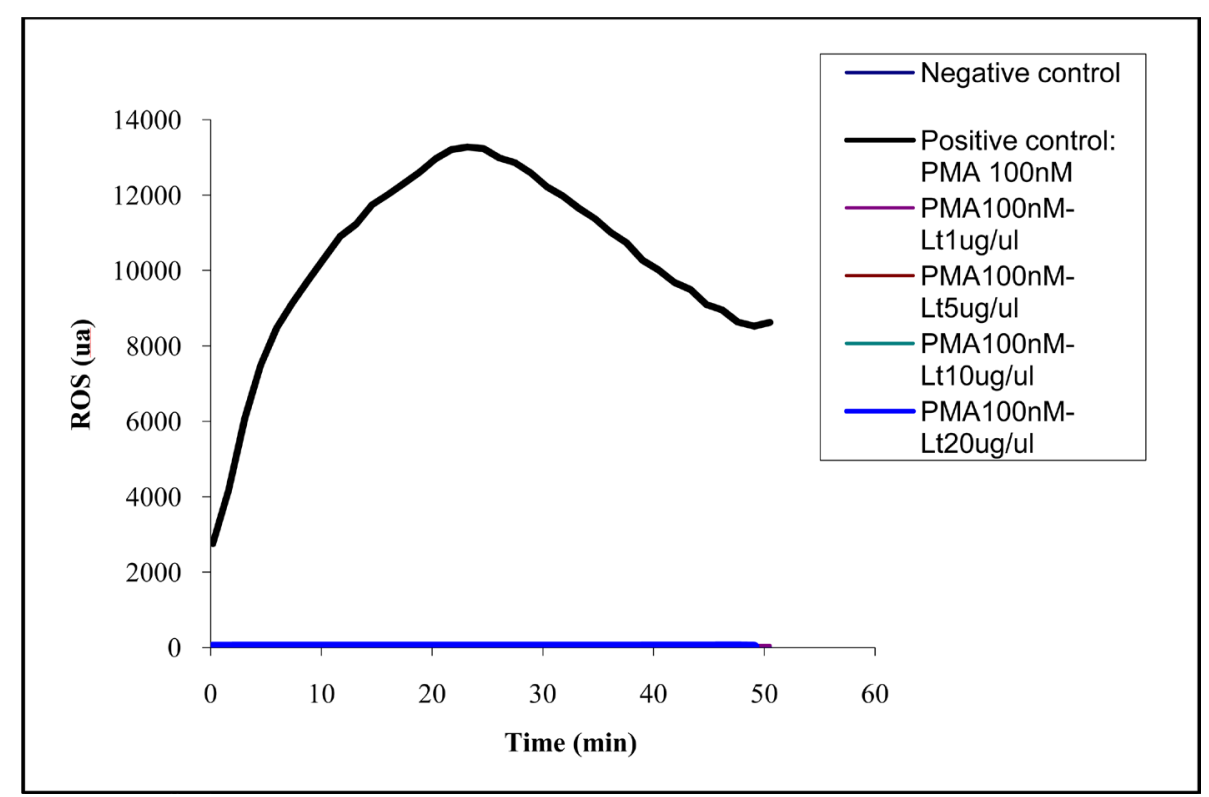

Figure 3. Phagocytes PLB985 stimulated with PMA in the absence or presence of L. taraxacifolia leaves extracts. In the absence of extracts, PMA $100 \mathrm{nM}$ (positive control) induced a strong production of reactive oxygen species (ROS) upon addition to PLB985 phagocytes; 25 minutes after the addition the maximum production was observed before the decrease from 30 minutes to $50 \mathrm{mn}$. In the presence of extracts $(1-20 \mu \mathrm{g} / \mu \mathrm{l})$ no production of ROS was observed with PMA $100 \mathrm{nM}$. The curves superimposed with the negative control. 


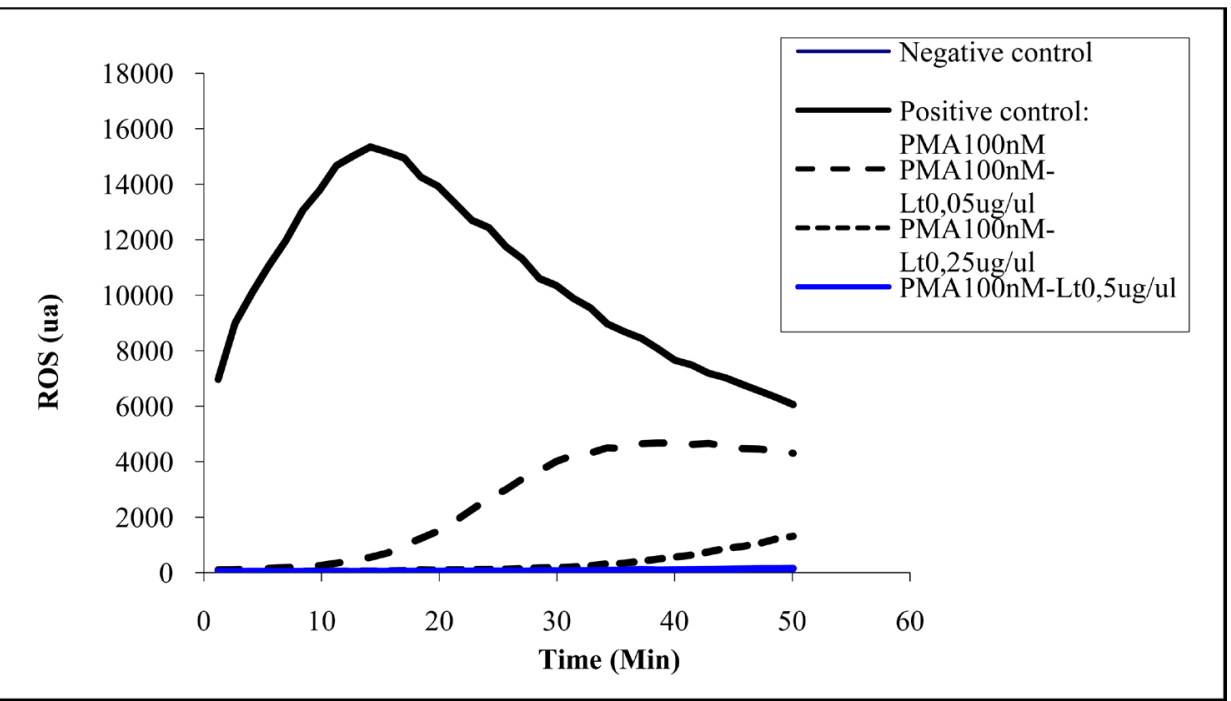

Figure 4. PLB985 phagocytes stimulated with PMA in the absence or presence of lower doses of L. taraxaciflolia leaves extracts. By decreasing the concentrations of extracts in the well, the doses of 0.05 and $0.25 \mu \mathrm{g} / \mu \mathrm{l}$ showed slower and gradual decrease of the oxidizing action of PMA. $0.5 \mu \mathrm{g} / \mu \mathrm{l}$ of Launaea taraxacifolia leaves extracts totally inhibited the oxidizing action of PMA. The curve superimposed with the negative control.

proteins, and DNA [7]. The majority of cardiovascular disease results from complications of atherosclerosis. An important initiating event for atherosclerosis may well be the transport of oxidized low-density lipoprotein (Ox-LDL) across the endothelium into the artery wall [46]. Moreover, in the recent past, the role of the Angiotensin (AT1) receptor in regulating hypertension has been the subject of intense investigation in both in vitro and animal models. Angiotensin modulates hypertension through its effect on the renin-angiotensin system, and the stimulation of AT1 receptors in the vascular wall leads to activation of $\mathrm{NADH} / \mathrm{NAD}(\mathrm{P}) \mathrm{H}$ oxidase in vascular cells. The resultant oxidative stress is considered a unifying mechanism for hypertension and atherosclerosis [47] [48]. The role of oxydative stress associated with hyperlipidemia and hyperglycemia in the complication of diabetes is also elucidated [6]. The results we have obtained with the phytochemical screening of L. taraxacifolia leaves extracts (see Figure 1) demonstrated the presence of a high proportion of polyphenols compounds and are consistent with previous works [13] [14] that showed the presence of flavonoid, tannin, ascorbic acids in $L$. taraxacifolia leaves extracts. The antioxidant property of polyphenols is well known, the hydrophobicity of polyphenols is intermediate between that of vitamin C (high hydrophilic) and that of vitamin E (high hydrophobic). Polyphenols are thus expected to be involved in oxidation regeneration pathway with vitamin $\mathrm{C}$ and $\mathrm{E}$ [36]. Glucuronidation, and sulfatation reduce the antioxidant capacity of polyphenols, catechin and quercetin protected more efficiently LDL from in vitro oxidation than the conjugated derivatives of the polyphenols [49] [50]. Plasma metabolites of catechin inhibited monocytes adhesion to interleukin $\beta$ stimulated human aortic endothelial cells [51]; quercetin 3-O-glucuronide prevented vascular smooth muscle cell hypertrophy induced by angiotensin II [52]. Polyphenols could thus prevent from cardiovascular diseases, cancer or diabetes. The medicinal properties (anti-inflammatory, hepato-protective, hypotensive and hypoglycemic) attributed to L. taraxacifolia could be due to the high proportion of polyphenols contained in the plant leaves.

\subsection{The Hypolipidemic Activity of L. taraxacifolia Leaves Extracts (Figure 5)}

The hypolipidemic activity of $L$. taraxacifolia leaves extract was investigated by measuring it effect on lipid accumulation induced by oleic acid in HepG2 cells. " $1 \mathrm{mM}$ " of oleic acid induced lipid accumulation (steatosis) in HepG2 cells [53]. The lipid accumulation was quantified by the "Oil Red O" which is a liposoluble lysochrome which stains in contact with lipids [31]. In this work we induced lipids accumulation in HepG2 cells in the presence or absence of $L$. taraxacifolia leaves extracts. Our results have shown that oleic acid $1 \mathrm{mM}$ induced lipid accumulation in HepG2 cells which were not treated with extracts (Figure 5(a)). But when the cells were treated with " $20 \mu \mathrm{g} / \mu \mathrm{l}$ " of extracts, "1 mM" of oleic acid did not induce lipid accumulation in HepG2 cells (Figure 5(b)). L. taraxacifolia leaves extracts could inhibit lipid accumulation induced by oleic acid in HepG2 


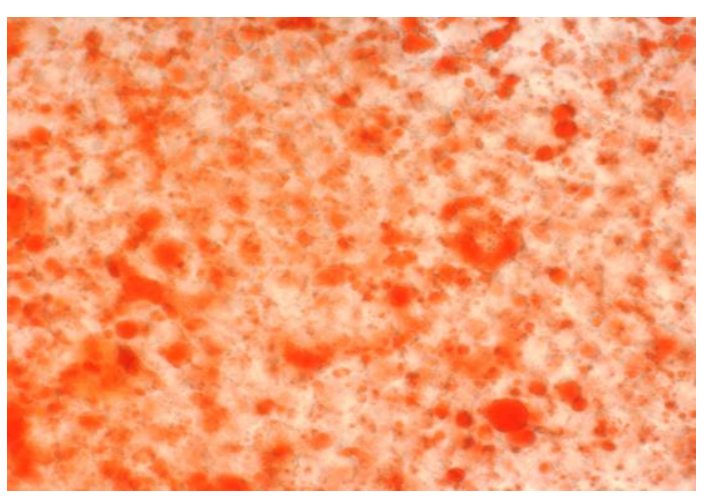

(a) Oleic acid $1 \mathrm{mM}$-Lt $0 \mu \mathrm{g} / \mu \mathrm{l}$ for $24 \mathrm{~h}$.

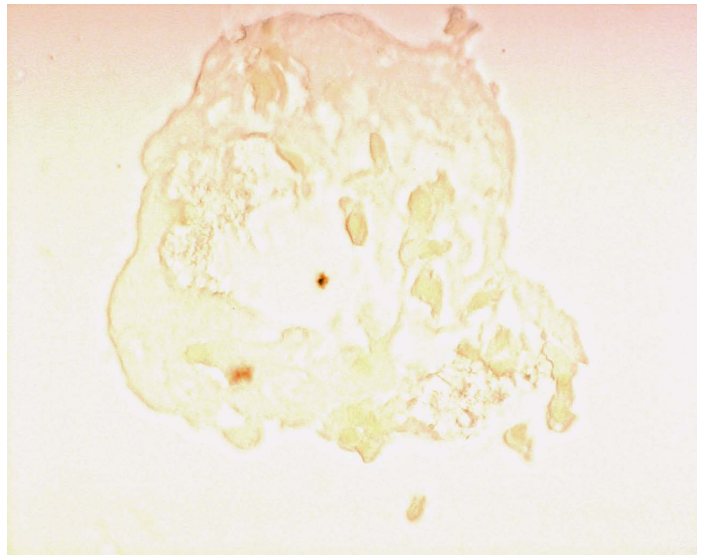

(b) Oleic acid $1 \mathrm{mM}$ and L. taraxacifolia $20 \mu \mathrm{g} / \mu \mathrm{l}$ for $24 \mathrm{~h}$.

Figure 5. Launaea taraxacifolia leaves extracts action on lipid accumulation induced by oleic acid in HepG2 cells. (a) Incubation for $24 \mathrm{~h}$ of HepG2 cells in the presence of oleic acid $1 \mathrm{mM}$ induced lipid accumulation in the intracellular medium; (b) Incubation for $24 \mathrm{~h}$ of HepG2 cells in the presence of oleic acid $1 \mathrm{mM}$ and L. taraxacifolia extracts $20 \mu \mathrm{g} / \mu \mathrm{l}$ did not induce lipid accumulation in the intracellular medium: L. taraxacifolia extracts could inhibit lipid accumulation induced by oleic acid in HepG2 cells.

cells. The recent works demonstrated that Oleic acid induced steatosis significantly increased TNF- $\alpha$ production and secretion in HepG2 cells [32]. TNF $\alpha$ stimulates ROS generation and induces lipid peroxidation [54]. Oleic acid induced steatosis would also be associated with a significantly decrease of superoxide dismutase (SOD-1), a free radical scavenger enzyme that protects against cellular membrane injury mediated by lipid peroxidation [32]. Considering these results we could suggest that $L$. taraxacifolia leaves extracts inhibited lipid accumulation in HepG2 cells via the antioxydant activities of the polyphenols present in the plant leaves. L. taraxacifolia leaves extracts could then prevent from non-alcoholic fatty liver disease (NAFLD).

\section{Conclusion}

Our results showed that the ethanol-aqueous extracts of $L$. taraxacifolia leaves were toxic only at very high concentrations. These leaves can be consumed both in food and as an infusion without risk of toxicity. However as a bioactive substance the dosage must be controlled since the very high doses are toxic. The phytochemical characterization we achieved showed that the leaves extracts contained a high proportion of polyphenols which may account for the reported medicinal properties of the plant. L. taraxacifolia leaves extracts could help to prevent or fight against non-communicable diseases such as cardiovascular diseases, diabetes and cancer. We therefore recommend the domestication of this plant in Benin since it can be used as a health food.

\section{References}

[1] Knobler, H., Schattner, A., Zhornicki, T., Malnick, S.D.H., Keter, D., Sokolovskaya, N. and Lurie, Y. (1999) Fatty 
Liver-An Additional and Treatable Feature of the Insulin Resistance Syndrome. Quarterly Journal of Medicine, 92, 73-79. http://dx.doi.org/10.1093/qjmed/92.2.73

[2] Day, C.P. and James, O.F.W. (1998) Steatohepatitis: A Table of Two Hits? Gastroenterology, 114, 842-845. http://dx.doi.org/10.1016/S0016-5085(98)70599-2

[3] Browning, J.D. and Horton, J.D. (2004) Molecular Mediators of Hepatic Steatosis and Liver Injury. The Journal of Clinical Investigation, 114, 147-152. http://dx.doi.org/10.1172/JCI200422422

[4] Belfort, R., Mandarino, L., Kashyap, S., Wirfel, K., Pratipanawatr, T., Berria, R., DeFronzo, R.A. and Cusi, K. (2005) Dose-Response Effect of Elevated Plasma Free Fatty Acid on Insulin Signalling. Diabetes, 54, 1640-1648. http://dx.doi.org/10.2337/diabetes.54.6.1640

[5] Higashi, Y., Sasaki, S., Nagakawa, K., Matsuura, H., Oshima, T. and Chayama, K. (2002) Endothelial Function and Oxydative Stress in Renovascular Hypertension. New England Journal of Medicine, 346, 1954-1962. http://dx.doi.org/10.1056/NEJMoa013591

[6] Heistad, D.D. (2006) Oxidative Stress and Vascular Disease. Arteriosclerosis, Thrombosis, and Vascular Biology, 26, 689-695. http://dx.doi.org/10.1161/01.ATV.0000203525.62147.28

[7] Madamanchi, N.R., Vendrov, A. and Runge, M.S. (2005) Oxidative Stress and Vascular Disease. Arteriosclerosis, Thrombosis, and Vascular Biology, 25, 29-38.

[8] Adebisi, A.A. (2004) Launaea taraxacifolia (Willd.) Amin ex C. Jeffrey. In: Grubben, G.J.H. and Denton, O.A., Eds., PROTA 2: Vegetables/Légumes.

[9] Dansi, A., Vodouhè, R., Azokpota, P., Yedomonhan, H., Assogba, P., Adjatin, A., Loko, L., Dossou-Aminon, I. and Akpagana, K. (2012) Diversity of the Neglected and Underutilized Crop Species of Importance in Benin. Scientific World Journal, 2012, 932-947. http://dx.doi.org/10.1100/2012/932947

[10] Dansi, A., Adjatin, A., Adoukonou-Sagbadja, H., Faladé, V., Yedomonhan, H., Odou, D. and Dossou, B. (2008) Traditional Leafy Vegetables and Their Use in the Benin Republic. Genetic Resources and Crop Evolution, 55, 1239-1256. http://dx.doi.org/10.1007/s10722-008-9324-z

[11] Obi, R.K. (2011) Antiviral Potential of Vegetables: Can They Be Cost-Effective Agents for Human Disease? Nutrients, Dietary Supplements, and Nutriceuticals, 5, 259-276. http://dx.doi.org/10.1007/978-1-60761-308-4 16

[12] Wallace, P.A., Marfo, E.K., Timpoh, G. and Plahar, W.A. (1996) Nutritional Value and Cholesterol-Lowering Effect of Wild Lettuce (Launaea taraxacifolia) Leaf Protein. Book of Abstracts, Ghana Science Association, Cape Coast, 14.

[13] Arawande, J.O., Amoo, I.A. and Lajide, L. (2013) Chemical and Phytochemical Composition of Wild Lettuce Launaea taraxacifolia. Journal of Applied Phytotechnology in Environmental Sanitation, 2, 25-30.

[14] Adinortey, M.B., Sarfo, J.K., Quayson, E.T., Weremfo, A., Adinortey, C.A., Ekloh, W. and Ocran, J. (2012) Phytochemical Screening, Proximate and Mineral Composition of Launaea taraxacifolia Leaves. Research Journal of Medicinal Plants, 6, 171-179.

[15] Randerath, K. (1971) Chromatographie sur Couches Minces. Edition Gauthier-Villars, Paris, 337-339.

[16] Rizk, A.M. (1982) Constituents of Plants Growing in Qatar. Fitoterapia, 52, 35-42.

[17] Dohou, N., Yamni, K., Tahrouch, S., Idrissi Hassani, L.M., Badoc, A. and Gmira, N. (2003) Screening phytochimique d'une endémique ibéro-marocaine, Thymelaea lythroides. Bulletin de la Société de pharmacie de Bordeaux, 142, 6178.

[18] Ribéreau-Gayon, J. and Peynaud, E. (1968) Les composés phénoliques des végétaux, Traité d’oenologie. Edition Dunod, Paris.

[19] Bruneton, J. (1993) Pharmacognosie, phytochimie, plantes médicinales. 2e edition, Tec et Doc., Lavoisier, Paris, 915 p.

[20] Bruneton, J. (1999) Pharmacognosy, Phytochemistry, Medicinal Plants. Lavoisier Technique \& Documentation, Paris. (In French)

[21] Traore, F. (2010) Proposition de formulation d'un sirop antipaludique à base de argemon emexican papaveraceae. Médecine, de Pharmacie et d'Odonto Stomatologie du Mali, 94 p.

[22] Singleton, V.I. and Lamuela-Raventos, R.M. (2012) Analysis of Total Phenols and Other Oxidation Substrates and Antioxidants by Means of Folin-Ciocalteu Reagent. Method in Enzymology, 299, 15.

[23] Siddhuraju, P., Mohan, P.S. and Becker, K. (2007) Studies on the Antioxidant Activity of Indian Laburnum (Cassia fistula L.), a Preliminary Assessment of Crude Extracts from Stem Bark, Leaves, Flowers and Fruit Pulp. Journal of Food Chemistry, 9, 61-67.

[24] Bahorun, T., Grinier, B., Trotin, T., Brunet, G., Pin, T., Lunck, M., Vasseur, J., Cazi, M., Cazin, C. and Pinkas, M. (1996) Oxygen Species Scavenging Activity of Phenolic Extracts from Hawthorn Fresh Plant Organs and Pharmaceutical Preparations. Arzneimittel-Forsching, 46, 1086-1089. 
[25] Agbangnan, C.P., Tachon, C., Bonin, C., Chrostowka, A., Fouquet, E. and Sohounhloue, D.K.C. (2012) Phytochemical Study of a Tinctorial Plant of Benin Traditional Pharmacopoeia: The Red Sorghum (Sorghum caudatum) of Benin. Scientific Study \& Research, 13, 121-135.

[26] Xu, B.J. and Chang, S.K.C. (2007) Comparative Study on Phenolic Profiles and Antioxidant Activities of Legumes as Affected by Extraction Solvents. Journal of Food Science, 72, 160-161. http://dx.doi.org/10.1111/j.1750-3841.2006.00260.x

[27] Kent, A.T., Mickael, B.L., Louis Jr., H. and Thomas, A.R. (1987) Characterization of a New Human Diploid Myeloid Leukemia Cell Line (PLB985) With Granulocytic and Monocytic Differentiating Capacity. Blood, 70, 372-378.

[28] Tlili, A., Erard, M., Faure, M.-C., Baudin, X., Piolot, T., Dupré-Crochet, S. and Nüsse, O. (2012) Stable Accumulation of $\mathrm{p}^{\mathrm{phox}}$ at the Phagosomal Membrane and ROS Production within the Phagosome. Journal of Leukocyte Biology, 91, 83-95. http://dx.doi.org/10.1189/jlb.1210701

[29] Mosmann, T. (1983) Rapid Colorimetric Assay for Cellular Growth and Survival: Application to Proliferation and Cytotoxity Assays. Journal of Immunological Methods, 65, 55-63. http://dx.doi.org/10.1016/0022-1759(83)90303-4

[30] Said, O., Saad, B., Fulder, S., Amin, R., Kassis, E. and Khalil, K. (2009) Hypolipidemic Activity of Extracts from Eriobotrya japonica and Olea europaea, Traditionally Used in the Greco-Arab Medicine in Maintaining Healthy Fat Levels in Blood. The Open Complementary Medicine Journal, 1, 84-91.

[31] Carson, F.L. (1997) Histotechnology: A Self-Instructional Text. 2nd Edition, American Society for Clinical Pathology Press, Chicago, 160.

[32] Cui, W., Chen, S.L. and Hu, K.Q. (2010) Quantification and Mechanisms of Oleic Acid-Induced Steatosis in HepG2 Cells. American Journal of Translational Research, 2, 95-104.

[33] Helen, L., Per, F., Laila, K. and Claes, D. (1995) Phorbol Myristate Acetate-Induced NADPH Oxidase Activity in Human Neutrophils: Only Half the Story Has Been Told. Journal of Leukocyte Biology, 59, 270-279.

[34] Natacha, S., Jean-Pol, F., Marie-Jose, S., Marie, E., Rachel, B., Christiane, T., Isabelle, D. and Oliver, N. (2007) Potent Inhibition of Store-Operated Ca2 Influx and Superoxide Production in HL60 Cells and Polymorphonuclear Neutrophils by the Pyrazole Derivative BTP2. Journal of Leukocyte Biology, 81, 1054-1064.

[35] Popovici, C., Saykova, I. and Tylkowski, B. (2009) Evaluation de l’activité antioxydante des composés phénoliques par la réactivité avec le radical libre DPPH. Revue de Génie Industriel, 4, 25-39.

[36] Manach, C., Scalbert, A., Morand, C., Rémésy, C. and Jiménez, L. (2004) Polyphenols: Food Sources and Bioavailability. American Journal of Clinical Nutrition, 79, 727-747.

[37] Berridge, M.V., Herst, P.M. and Tan, A.S. (2005) Tetrazolium Dyes as Tools in Cell Biology: New Insights into Their Cellular Reduction. Biotechnology Annual Review, 11, 127-152. http://dx.doi.org/10.1016/S1387-2656(05)11004-7

[38] Berridge, M.V. and Tan, A.S. (1993) Characterization of the Cellular Reduction of 3-(4,5-dimethylthiazol-2-yl)-2,5diphenyltetrazolium Bromide (MTT): Subcellular Localization, Substrate Dependence, and Involvement of Mitochondrial Electron Transport in MTT Reduction. Archives of Biochemistry and Biophysics, 303, 474-482. http://dx.doi.org/10.1006/abbi.1993.1311

[39] Kuhnau, J. (1976) The Flavonoids. A Class of Semi-Essential Food Components: Their Role in Human Nutrition. World Review of Nutrition and Dietetics, 24, 117-191. http://dx.doi.org/10.1159/000399407

[40] Radtke, J., Linseisen, J. and Wolfram, G. (1998) Phenolic Acid Intake of Adults in a Bavarian Subgroup of the National Food Consumption Survey. Zeitschrift für Ernährungswissenschaft, 37, 190-197. http://dx.doi.org/10.1007/s003940050016

[41] Graefe, E.U., Wittig, J., Mueller, S., Riethling, A.K., Uehleke, B., Drewelow, B., et al. (2001) Pharmacokinetics and Bioavailability of Quercetin Glycosides in Humans. The Journal of Clinical Pharmacology, 41, 492-499. http://dx.doi.org/10.1177/00912700122010366

[42] Chang, H.C., Churchwell, M.I., Delclos, K.B., Newbold, R.R. and Doerge, D.R. (2000) Mass Spectrometric Determination of Genistein Tissue Distribution in Diet-Exposed Sprague-Dawley Rats. Journal of Nutrition, 130, 1963-1970.

[43] Kim, S.B., Lee, M.J. and Hong, J.I. (2000) Plasma and Tissue Levels of Tea Catechins in Rats and Mice during Chronic Consumption of Green Tea Polyphenols. Nutrition and Cancer, 37, 41-48. http://dx.doi.org/10.1207/S15327914NC3701_5

[44] Schramm, D.D., Collins, H.E. and German, J.B. (1999) Flavonoid Transport by Mammalian Endothelial Cells. The Journal of Nutritional Biochemistry, 10, 193-197. http://dx.doi.org/10.1016/S0955-2863(98)00104-1

[45] Maubach, J., Bracke, M.E., Heyerick, A., Depypere, H.T., Serreyn, R.F., Mareel, M.M. and De Keukeleire, D. (2003) Quantitation of Soy-Derived Phytoestrogens in Human Breast Tissue and Biological Fluids by High-Performance Liquid Chromatography. Journal of Chromatography B, 784, 137-144. http://dx.doi.org/10.1016/S1570-0232(02)00789-4

[46] Navab, M., Berliner, J.A., Watson, A.D., Hama, S.Y., Territo, M.C., Lusis, A.J., Shih, D.M., Van Lenten, B.J., Frank, 
J.S., Demer, L.L., Edwards, P.A. and Fogelman, A.M. (1996) The Yin and Yang of Oxidation in the Development of the Fatty Streak: A Review Based on the 1994 George Lyman Duff Memorial Lecture. Arteriosclerosis, Thrombosis, and Vascular Biology, 16, 831-842. http://dx.doi.org/10.1161/01.ATV.16.7.831

[47] Wassmann, S., Laufs, U., Baumer, A.T., Muller, K., Konkol, C., Sauer, H., Bohm, M. and Nickenig, G. (2001) Inhibition of Geranyl Geranylation Reduces Angio Tensin II-Mediated Free Radical Production in Vascular Smooth Muscle Cells: Involvement of Angiotensin AT1 Receptor Expression and Rac1 GTPase. Molecular Pharmacology, 59, 646654.

[48] Touyz, R.M., Yao, G. and Schiffrin, E.L. (2003) c-Src Induces Phosphorylation and Translocation of p47 ${ }^{\text {phox }}$ : Role in Superoxide Generation by Angiotensin II in Human Vascular Smooth Muscle Cells. Arteriosclerosis, Thrombosis, and Vascular Biology, 23, 981-987. http://dx.doi.org/10.1161/01.ATV.0000069236.27911.68

[49] Moon, J.H., Tsushida, T., Nakahara, K. and Terao, J. (2001) Identification of Quercetin 3-O- $\beta$-D-Glucuronide as an Antioxidative Metabolite in Rat Plasma after Oral Administration of Quercetin. Free Radical Biology and Medicine, 30, 1274-1285. http://dx.doi.org/10.1016/S0891-5849(01)00522-6

[50] Cren-Olive, C.C., Teissier, E., Duriez, P. and Rolando, C. (2003) Effect of Catechin O-Methylated Metabolites and Analogues on Human LDL Oxidation. Free Radical Biology and Medicine, 34, 850-855. http://dx.doi.org/10.1016/S0891-5849(02)01433-8

[51] Koga, T. and Meydani, M. (2001) Effect of Plasma Metabolites of (+)-Catechin and Quercetin Onmonocyte Adhesion to Human Aortic Endothelial Cells. American Journal of Clinical Nutrition, 73, 941-948.

[52] Yoshizumi, M., Tsuchiya, K. and Suzaki, Y. (2002) Quercetin Glucuronide Prevents VSMC Hypertrophy by Angiotensin II via the Inhibition of JNK and AP-1 Signaling Pathway. Biochemical and Biophysical Research Communications, 293, 1458-1465. http://dx.doi.org/10.1016/S0006-291X(02)00407-2

[53] Janorkar, A.V., King, K.R., Megeed, Z. and Yarmush, M.L. (2009) Development of an in Vitro Cell Culture Model of Hepatic Steatosis Using Hepatocyte-Derived Reporter Cells. Biotechnology and Bioengineering, 102, 1466-1474. http://dx.doi.org/10.1002/bit.22191

[54] Evereklioglu, C., Turkoz, Y., Calis, M., Duygulu, F. and Karabulut, A.B. (2004) Tumor Necrosis Factor Alpha, Lipid Peroxidation and NO Are Increased and Associated with Free Radical Scavenging Enzymes in Patients with WeillMarchesani Syndrome. Mediators of Inflammation, 13, 165-170. http://dx.doi.org/10.1080/09511920410001713547 